\title{
STUDY OF PLASMA ION NITRIDING OF AISI H13 STEEL
}

\author{
M. C. L. Souzaa ${ }^{\text {, ABSTRACT }}$ \\ G. R. da Silva ${ }^{a}$, \\ E. S. Souzab, \\ This work studied the thermochemical treatment of AISI H13 steel \\ W. C. L. Pinto ${ }^{a}$, \\ used for extrusion of aluminum parts, by plasma ionic nitriding, with \\ the objective of increasing the surface hardness of the mold, by \\ forming an external layer of stable nitrides, increasing the resistance \\ and N. C. O. Tapanes ${ }^{a}$ \\ to wear, fatigue, corrosion and thermal resistance. Because it uses \\ ions, plasma ion nitriding is more efficient than liquid and gas \\ ${ }^{\text {a }}$ Centro Universitário Estadual da Zona Oeste \\ Engineering School \\ Av. Manuel Caldeira de Alvarenga, 1203, Rio \\ de Janeiro - RJ, 23070-200, Brasil \\ mauroclsouza@hotmail.com

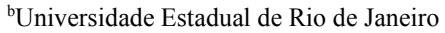 \\ Mechanical Engineering Department \\ Maracanã, Rio de Janeiro, RJ. 20.550-030 \\ Brasil. \\ Received: Jul 21, 2020 \\ Revised: Dec 10, 2020 \\ Accepted: Dec 12, 2020 \\ nitriding. This process is widely used for ferrous materials and \\ aluminum. The main applications are for extrusion, material injection \\ molds, cutting tools and automotive parts. In this work, samples of \\ the AISI H13 steel were nitrided to be used as aluminum injection \\ molds. The treatment was carried out at $300{ }^{\circ} \mathrm{C}$ in a sodium cyanide \\ bath, for a period of $6 \mathrm{~h}$ at a pressure of $15 \mathrm{mTorr}(2 \mathrm{~Pa})$. The gaseous \\ mixture inside the nitreter consisted of $80 \% \mathrm{~N}_{2}+20 \% \mathrm{H}_{2}$. After \\ treatment, Vickers hardness measurements reached surface values of \\ $963 \mathrm{HV}$. The results at the end of the treatment showed a $122 \mu \mathrm{m}$ \\ nitrided layer. \\ Keywords: plasma ion nitriding; hardness; heat resistance; wear
}

\section{NOMENCLATURE}

$\begin{array}{ll}\text { AISI } & \text { American Iron Steel Institute } \\ \text { u.a. } & \text { arbitrary unit } \\ \text { BCC } & \text { Body-centered cubic } \\ \text { CH } & \text { Compact Hexagonal } \\ \text { FCC } & \text { Face-centered cubic } \\ \text { HV } & \text { Vickers hardness } \\ \mathrm{I} & \text { Intensity } \\ \mathrm{kPa} & \text { Kilopascal } \\ \mathrm{kV} & \text { Kilovolts } \\ \mu \mathrm{m} & \text { Micrometer } \\ \mathrm{mT} \text { Torr } & \text { Millitorr } \\ \mathrm{Pa} & \text { Pascal } \\ \mathrm{SEM} & \text { Scanning Electron Microscope } \\ \mathrm{V} & \text { Volts }\end{array}$

\section{INTRODUCTION}

One of the areas of material development that has advanced rapidly on the planet is surface engineering. It mainly aims to develop new composite materials, with the presence of a surface layer and substrate, which present combinations of specific and more improved physical-chemical and mechanical properties (Shewman, 1993).

Economically viable and known steels are possible to be treated and transformed in their surface layer so that they can be used in applications that would be impossible to be supported by the base materials (substrate), in addition to being much more economical than developing new alloys and producing new ones. materials (Zampronio, 1995).

Surface treatment techniques fall into two categories: those that involve deposition of a surface layer on a substrate and those that are obtained by treatments that result in a physical-chemical modification of a surface region of the substrate and, in the latter category, includes plasma ion nitriding.

Plasma ion nitriding is, within surface engineering, a technique that results in a change in the surface region of the substrate and can generate two distinct layers: white or composite layer, consisting of nitrides and thickness that can reach 50 $\mu \mathrm{m}$ and the zone diffusion with nitrogen in solid solution in the ferrite and nitrides with a thickness that can reach $900 \mu \mathrm{m}$ (Keller, 1981).

Recently, there has been an increasing use of this technique, which aims to improve the surface properties of metallic materials. The results confirm greater fatigue resistance, much better wear resistance, mainly for hot work and corrosion resistance. Hardness reaches high values. Another advantage is a huge reduction in the diffusion of hydrogen, which is known to weaken the steels. The hydrogen protons permeate easily through the crystalline network of the steels and the plasma ion nitriding process has been shown to be very efficient 
in blocking the diffusion of hydrogen (Bott et al., 1997).

Plasma ion nitriding has been replacing traditional and conventional nitriding processes for a long time. The advantages range from ease and speed to reduced costs, when compared to conventional processes such as, for example, lower temperatures (on the order of $300 \mathrm{oC}$ ). In this process, a voltage, which can vary from $300 \mathrm{~V}$ to about $1400 \mathrm{~V}$, is applied between the part (cathode) and a stainless steel grid (anode) located around the part. In this way, an electric current conducts the nitrogen ions into the part, where it forms stable nitrides (Zampronio et al., 1994).

Plasma ion nitriding was created by J. J. Egan to reduce nitriding time. It is a thermochemical process that has been used in industry since the 70's (Kornhonen et al., 1982), to improve the surface properties of tools and mechanical components, obtaining greater hardness, resistance to wear, corrosion and fatigue. The White layer, or compound zone, is made up mostly of nitrides and the diffusion zone contains nitrogen in solid interstitial solution, or in the form of nitride (Pye, 2003; Rocha et al., 1996). In this process, the nitrogen ion derived from pure gas or gas mixtures (usually with hydrogen) containing nitrogen is used under a pressure ranging from 1 to $8 \mathrm{kPa}$. The renewal of the atmosphere inside the nitreter must be dynamic.

In this study, AISI H13 steel, used in the making of molds for aluminum extrusion, was nitrided by the plasma ion nitriding process, with the objective of studying the increase in surface hardness, which is fundamental; therefore, hot extrusion can cause undesirable wear on the molds.

\section{MATERIAL AND METHODS}

\section{Material}

The steel used as a substrate was AISI H13 steel, manufactured by industries for the production of molds for the extrusion. The percentage chemical composition of H13 Steel, used in ion nitriding work, is shown in Table 1.

Table 1. Chemical Analysis of H13 Steel (\%)

\begin{tabular}{|c|c|c|c|c|c|c|c|c|}
\hline AISI & C & Mn & P & S & Si & Cr & Mo & V \\
\hline H13 & 0.43 & 0.36 & 0.03 & 0.01 & 1.16 & 5.36 & 1.36 & 1.01 \\
\hline
\end{tabular}

This tool steel is intended for the manufacture of dies for hot forging in presses, manufacture of injection molds, tools for hot cutting, dies for the casting of aluminum alloys, lead, tin and zinc and tools for extrusion of light alloys . Hot-working steel, bonded to chromium-molybdenum-vanadium, temperable in oil or air, with excellent toughness, high mechanical resistance, good resistance to wear at high temperatures. It has good resistance to thermal fatigue, thermal shock and softening by heat.

\section{Methodology}

The nitriding of the samples was carried out in the nitreter shown in the diagram in Figure 1, being: 1 - Nitriding chamber, with body Pyrex Glass; 2 Gas mixer; 3 - Vacuum System (with mechanical pump and diffuser pump); 4 - Voltage source.

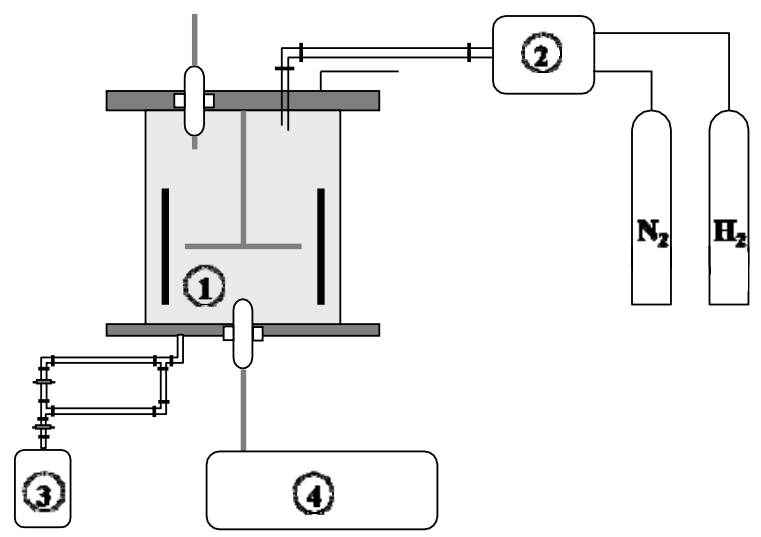

Figure 1. Schematic diagram of the nitreter.

The samples were ionically nitrided by plasma on one side and the nitriding conditions are shown in Table 2.

Table 2. Process parameters.

\begin{tabular}{|l|c|}
\hline PARAMETER & VALUES \\
\hline Temperature & $300{ }^{\circ} \mathrm{C}$ \\
\hline Pressure & $15 \mathrm{mTorr}(\sim 2 \mathrm{~Pa})$ \\
\hline Nitriding time & 6 hours \\
\hline Applied voltage & $500 \mathrm{~V}$ \\
\hline Current Density & $5.25 \mathrm{~mA} / \mathrm{cm}^{2}$ \\
\hline Gas mixture $\mathrm{N}_{2} / \mathrm{H}_{2}$ & $80 \% / 20 \%$ \\
\hline
\end{tabular}

\section{Experimental Techniques}

The x-ray diffractometry method was used to characterize the nitrided layer to determine the types of nitrides present in the white layer and in the diffusion zone. The Shimadzu equipment model LAB XRD 6000 was used. The equipment has a copper target, agate monochromator and $\mathrm{NaI}$ detector (Tl). It operated with a voltage of $40 \mathrm{KV}$ and a current of $30 \mathrm{~mA}$.

The Scanning Electron Microscope (SEM), JEOL JSM6460 LV, was used in the microstructure analysis of both the substrate (H13 steel) and the nitrided layer.

The hardness measurements of the nitrided samples were performed by Vickers microhardness (HV). The LEITZ Microhardness Testers, Model NR498366, with a load of $80 \mathrm{~g}$ was used. 


\section{RESULTS AND DISCUSSION}

The white layer, which is the surface layer of the piece, exhibited a thickness of $16 \mu \mathrm{m}$. X-ray diffraction was shown to be composed of the $\gamma$ ' $\mathrm{Fe}_{4} \mathrm{~N}$ (FCC) and $\varepsilon \mathrm{Fe}_{2} \mathrm{~N}(\mathrm{CH})$ phases. The intensity of the peaks suggests that the $\gamma$ 'phase predominates. Zampronio, 1995, also observed this predominance in plasma-nitrided samples at $400{ }^{\circ} \mathrm{C}$.

SEM micrographs showed that the $\gamma$ 'phase is more superficial and that the $\varepsilon$ phase only begins to appear at depths greater than $1.2 \mu \mathrm{m}$. This finding was also confirmed by X-ray diffraction measurements, using very small angles, between $1 \mathrm{st}$ and 2 nd, practically level to the sample surface. The observations in the SEM made it possible to measure the total thickness of the nitrided layer, which reached $122 \mu \mathrm{m}$.

$\mathrm{X}$-ray diffractograms suggest intergranular phases that have the same morphology as the $\alpha$ "phase $\left(\mathrm{Fe}_{16} \mathrm{~N}_{2}\right)$, also found by Zampronio, 1995. Other authors think that this phase of acicular morphology is likely to be the a phase " (BCC), precipitated in grain contours, which is observed up to $60 \mu \mathrm{m}$ deep (Bott et al., 1997).

Figure 2 shows the diffractogram of the H13 Steel of the plasma nitrided layer, with the studied thickness of $122 \mu \mathrm{m}$. The Figure shows a $2 \theta$ angle scan from $30^{\circ}$ to $90^{\circ}$.

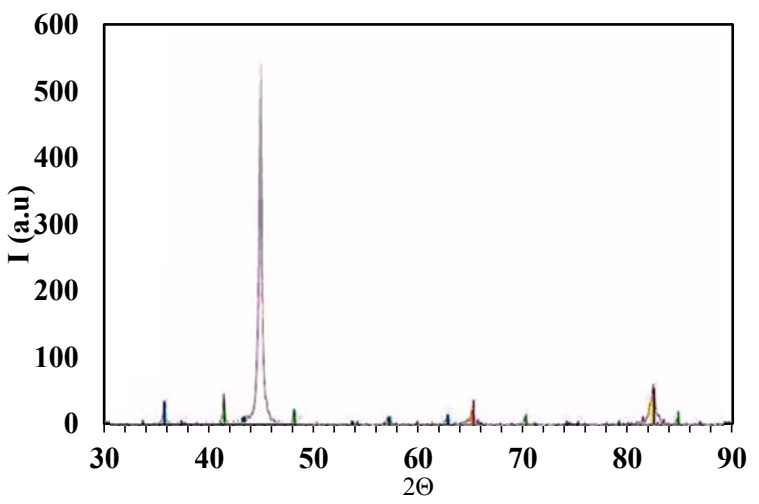

Figure 2. Diffractogram of the plasma-nitrided H13 steel sample, with a thickness of $122 \mu \mathrm{m}$.

In the diffractogram of Figure 2, in addition to the ferrite peak, which is the most prominent, the formation of the iron dichromate peaks, $\mathrm{Fe}_{2} \mathrm{Cr}_{2} \mathrm{O}_{4}$ and $\mathrm{Fe}_{2} \mathrm{~N}$ and $\mathrm{Fe}_{4} \mathrm{~N}$ nitrides is also observed. These two distinct phases $\left(\mathrm{Fe}_{2} \mathrm{~N}\right.$ and $\left.\mathrm{Fe}_{4} \mathrm{~N}\right)$, characterize the formation of the white layer in samples nitrided by plasma and, as described at the beginning of the present discussion, are also known as $\varepsilon$ and $\gamma$ 'phases, respectively. In the $\mathrm{Fe}-\mathrm{N}$ phase diagram, it can be seen that, for the temperature of $300^{\circ} \mathrm{C}$, used in nitriding, the $\gamma$ 'phase is present between $5.75 \%$ to $6.22 \%$ Nitrogen and the $\varepsilon$ phase above $8.32 \%$ Nitrogen.
The Vickers hardness measurements, performed with the microdurometer, using a load of $80 \mathrm{~g}$, are shown in Figure 3.

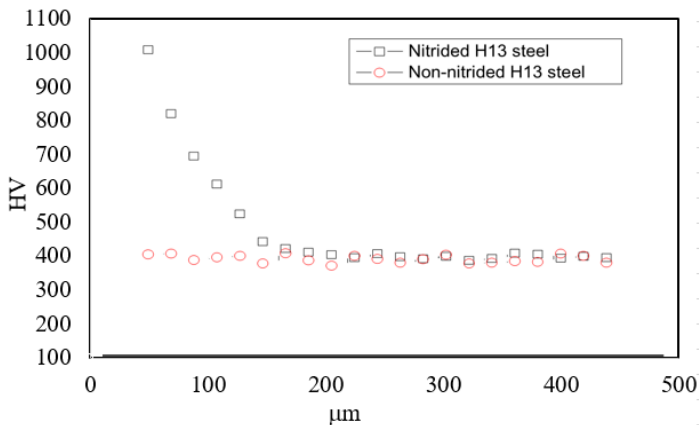

Figure 3. Vickers microhardness versus the depth of the nitrided layer.

As can be seen in Figure 3, the plasma ion nitriding treatment gave the $\mathrm{H} 13$ steel a high surface hardness, notably in the first $20 \mu \mathrm{m}$ of the surface. The surface hardness reached $963 \mathrm{HV}$. The reduction is smaller after $100 \mu \mathrm{m}$ and, after $150 \mu \mathrm{m}$, almost no difference is noticed between nitrided and nonnitrided steel. The hardness of AISI H13 Steel, used in this work, provided by the manufacturer is 475 HV. The measurements made on the substrate confirm that the values oscillate around this value.

\section{CONCLUSIONS}

The treatment by Plasma Ion Nitriding is very efficient for a large number of metals and alloys, especially for tool steels, when high surface hardness, in the order of 900-1100 HV, is required.

Through X-ray diffraction and SEM, it was possible to identify the formation of the white layer and the observation of nitrides $\left(\mathrm{Fe}_{2} \mathrm{~N}\right.$ and $\left.\mathrm{Fe}_{4} \mathrm{~N}\right)$ responsible for the high surface hardness.

The Vickers microhardness (HV) measurements showed the efficiency of the plasma nitriding process, when the initial hardness on the surface of the AISI H13 steel, of about $375 \mathrm{HV}$, was increased to 963 $\mathrm{HV}$, after nitriding.

\section{ACKNOWLEDGEMENTS}

The authors would like to thank the financial support given by the Research Support Foundation of the State of Rio de Janeiro (FAPERJ) to the study.

\section{REFERENCES}

Bott, A. H., Bruhl, S. P., Gomez, B., Zampronio, M. A., Feugas, J. N., De Miranda, P. E. V., 1997, Pulsed Plasma Nitrites, API 5L X-65 Steel: Permeability and Microestructural Aspects, J of Phys D: Appl Physics, Vol. 46, No.4, pp. 127-132. 
Keller, K., 1981, Layer Structure of Iron Materials in a Glow Discharge, Harterei - Technische Mitteilung, vol. 26, No. 1, pp 120-130.

Korhonen, A. S. Sirvio, E., 1982, A New LowPressure Plasma Nitriding Method, The Thin Solid Films, vol. 96, No.1, pp. 103-108.

Pye, D., 2003, Practical Nitriding and Ferritic Nitrocarburizing, ASM, International Materials Park, Ohio.

Rocha, A. S., Junior, M. W., Antonio, C., A. V., Strohaecker, T. R., 1997, Nitretação a Plasma de Aços Ferramenta, II Congresso Internacional de Tecnologia Metalúrgica e de Materiais, S. Paulo.

Shewman, P. G., 1993, Diffusion in Solids, McGraw-Hill Book Company.

Zampronio, M. A., 1995, Revestimentos Superficiais em Aço para Limitar Contaminação por Hidrogênio, 125 p. Tese (Doutorado em Metalurgia e Matérias, COPPE/UFRJ, Rio de Janeiro. Zampronio, M. A., Cabo, A., Bott, A. H., De Miranda, P. E. V., 1994, Surface Engineering to Extend Service Life: News Uses for Traditional Steels. In: CONGRESO INTERNACIONAL IEV, Buenos Aires, Anais: p. 253-256. 